\title{
Contrasting patterns of insect herbivory and predation pressure across a tropical rainfall gradient
}

Weissflog, Anita; Markesteijn, Lars; Lewis, Owen T.; Comita, Liza S.; Engelbrecht, Bettina M. J.

\section{Biotropica}

DOI:

10.1111/btp.12513

Published: 01/03/2018

Peer reviewed version

Cyswllt i'r cyhoeddiad / Link to publication

Dyfyniad o'r fersiwn a gyhoeddwyd / Citation for published version (APA):

Weissflog, A., Markesteijn, L., Lewis, O. T., Comita, L. S., \& Engelbrecht, B. M. J. (2018).

Contrasting patterns of insect herbivory and predation pressure across a tropical rainfall gradient. Biotropica, 50(2), 302-311. https://doi.org/10.1111/btp.12513

\footnotetext{
Hawliau Cyffredinol / General rights

Copyright and moral rights for the publications made accessible in the public portal are retained by the authors and/or other copyright owners and it is a condition of accessing publications that users recognise and abide by the legal requirements associated with these rights.

- Users may download and print one copy of any publication from the public portal for the purpose of private study or research.

- You may not further distribute the material or use it for any profit-making activity or commercial gain

- You may freely distribute the URL identifying the publication in the public portal ?
}

Take down policy

If you believe that this document breaches copyright please contact us providing details, and we will remove access to the work immediately and investigate your claim. 
3 LRH: Weissflog et al.

4 RRH: Herbivory and Predation across Rainfall Gradient

8 Contrasting patterns of insect herbivory and predation pressure across a tropical rainfall 9 gradient

Anita Weissflog ${ }^{1,2}$, Lars Markesteijn ${ }^{3,4,5}$, Owen T. Lewis ${ }^{5}$, Liza S. Comita ${ }^{3,6}$, Bettina M.J.

$14 \quad{ }^{1}$ Corresponding author: Anita1.Weissflog@uni-bayreuth.de; +49 304744950

${ }^{2}$ Department of Plant Ecology, Bayreuth Center of Ecology and Environmental Research

16 (BayCEER), 95440 Bayreuth, Germany

$17{ }^{3}$ Smithsonian Tropical Research Institute, Apartado 0843-03092, Balboa, República de Panama

$18{ }^{4}$ School of Environment, Natural Resources and Geography, Bangor University, Bangor,

19 Gwynedd LL57 2DG, UK

${ }^{5}$ Department of Zoology, University of Oxford, South Parks Road, Oxford OX1 3PS, UK

${ }^{6}$ School of Forestry and Environmental Studies, Yale University, New Haven, CT 06511, U.S.A. 
One explanation for the extraordinarily high tree diversity of tropical lowland forests is that it is maintained by specialized natural enemies such as insect herbivores, which cause distance- and density-dependent mortality. Insect herbivory could also explain the positive correlation between tree species richness and rainfall if herbivory increases with rainfall, is higher on locally abundant versus rare species, and is not limited by predation pressure at wet sites. To test these predictions, insect herbivory and predation pressure on insect herbivores were quantified across a neotropical rainfall and tree species richness gradient, and herbivory was investigated in relation to local tree abundances. Insect herbivory on leaves (folivory) decreased strongly and significantly with rainfall, while predation pressure was significantly higher at the wetter site. Herbivores were more likely to attack abundant tree species, but herbivore damage levels were not related to tree species abundance. Insect folivores might contribute to local tree species coexistence in our system, but seem unlikely to drive the positive correlation between tree species richness and rainfall. The unexpected and contrasting patterns of herbivory and predation we observed support the need for a multi-trophic perspective to understand fully the processes contributing to diversity and ecosystem functioning.

Una explicación para la extraordinaria elevada diversidad de los árboles en los bosques tropicales de tierras bajas es que esta mantenida por enemigos naturales especializados como insectos herbívoros, los cuales causan mortalidad dependiente a la densidad y a la distancia. La herbivoría de los insectos podría explicar también la correlación positiva entre la riqueza de especies arbóreas y la precipitación, si la herbivoría se incrementa con la precipitación, es mayor en especies con alta abundancia local versus las especies poco comunes, y no está limitado por la presión de la predación en lugares húmedos. Para comprobar estas predicciones, la herbívora por 
47 insectos y la presión de la predación en insectos herbívoros fueron cuantificadas, a lo largo de un 48 gradiente de precipitación neotropical y de riqueza de especies, y a su vez herbivoría fue

49 relacionada con las abundancias locales de 42 especies arbóreas de enfoque. La herbivoría de

50 insectos en las hojas (folivoria) decrece considerable y significantemente con la precipitación, 51 mientras que la presión por predación fue significativamente mayor en el sitio más húmedo. Con 52 una mayor probabilidad los herbívoros atacaron las especies más abundantes, pero el nivel de daño por herbivoría no estaba relacionado con la abundancia de las especies arbóreas. En nuestro

54 sistema, los insectos folívoros podrían contribuir a la coexistencia de las especies de árboles

55 locales, pero parece improbable llevar a la correlación positiva entre la riqueza de especies y la

56 precipitación. Los patrones inesperados y opuestos que se observaron de la herbivoría y la

57 predación apoyan la necesidad de un punto de vista multitrófico para entender completamente el proceso que contribuye a la diversidad y funcionamiento del ecosistema.

Key words: community compensatory trend; Janzen-Connell; Panama; precipitation; species coexistence

Tweetable abstract: Climate alters herbivory: in wetter rainforests, insects cause less damage and have higher risk of predation 
(Pyke et al. 2001; Leigh et al. 2004; Davidar et al. 2005). Understanding how abiotic and biotic factors interact in shaping and maintaining gradients in tree species richness, composition, and ultimately ecosystem functioning is crucial to predict the susceptibility of forests to climate change and to mitigate socio-economic consequences of forest degradation.

One of the most prominent large-scale patterns in tropical plant diversity is the tendency for tree species richness to increase with rainfall and decrease with seasonality (Givnish 1999; Leigh et al. 2004; Davidar et al. 2005). Enhanced density- and distance-dependent insect herbivory in less seasonal and more humid forests has been suggested to contribute to this pattern (Janzen 1970; Connell 1971; Coley \& Barone 1996; Leigh et al. 2004; Baltzer \& Davies 2012).

Specialized natural enemies such as insects can reduce the fitness of tree offspring growing close to conspecific adults, which serve as reservoirs for natural enemies, or at high conspecific offspring densities, which attract enemies via spatial resource concentration (Janzen 1970; Connell 1971; Root 1973). Conspecific negative density dependence (CNDD) has been widely documented in tropical forests (Peters 2003; Comita et al. 2010, 2014; Paine et al. 2012; Bagchi et al. 2014) and is regarded as an important mechanism contributing to the maintenance of high alpha-diversity in tropical forests (Janzen 1970; Connell 1971; Paine et al. 2012; Bagchi et al. 2014).

An increase in insect herbivore pressure with rainfall has been suggested to explain higher tree species richness in wet than in dry tropical forests (Janzen 1970; Connell 1971; Coley \& Barone 1996; Leigh et al. 2004; Baltzer \& Davies 2012). Insect herbivores, as the most important primary consumers in tropical forests, consume up to $\sim 70$ percent of total leaf area 
(Coley \& Barone 1996) and have been proposed as major agents of distance- and densitydependent effects on plant species (Leigh et al. 2004; Brenes-Arguedas et al. 2009). Drier and more seasonal conditions could reduce insect abundance by increasing desiccation risk (Coley \& Barone 1996; Givnish 1999; Connahs et al. 2011) and by causing resource limitation through decreased plant productivity (Coley \& Barone 1996; Leigh et al. 2004; Richards \& Coley 2007; Connahs et al. 2011). The hypothesized tendency for insect abundance to be higher in wetter, less seasonal forests is likely to translate into higher herbivory. However, empirical evidence is scarce and contradictory: insect abundance and herbivory have been shown to be higher (BrenesArguedas et al. 2009; Rodríguez-Castañeda 2013), lower (Coley \& Barone 1996; Leigh et al. 2004; Dirzo \& Boege 2008) or similar (Baltzer \& Davies 2012) in wet compared to dry tropical forests. Thus, it remains unclear whether insect herbivore pressure and CNDD do indeed increase with rainfall, and whether such a trend explains higher plant diversity in wetter tropical forests. In a recent meta-analysis, the strength of negative density- and distance-dependence was found to increase with increasing mean annual rainfall, suggesting that CNDD may contribute to increases in plant diversity along rainfall gradients (Comita et al. 2014). However, the degree to which this pattern is driven by insect herbivores or other mechanisms (e.g. pathogens, intraspecific competition) remains unknown.

The impact of CNDD may vary with the local abundance of tree species. Abundant species contribute more individuals per unit area, resulting in higher conspecific densities compared to rare species. Thus, natural enemies should have a higher chance to encounter, attack and build up populations if interacting with locally abundant species (Root 1973; Castagneyrol et al. 2014). In contrast, rare species that experience less herbivore damage would profit from a competitive advantage against abundant species, promoting species coexistence via a community 
111 compensatory trend (Leigh et al. 2004; Norghauer et al. 2006). In order for insects to contribute

112 to maintaining the high tree alpha-diversity of tropical forests via CNDD, the impact of insect

113 herbivory must increase with tree species abundance in a community.

114 The effects of insect herbivores on plants can be moderated by their predators, which can 115 effectively reduce insect herbivore populations (Purcell \& Avilés 2008) and herbivory (Mazía et 116 al. 2004; Stireman et al. 2005; Rodríguez-Castañeda 2013). Top-down control of herbivores has 117 been suggested to increase from dry to wet tropical forests (Root 1973; Oksanen et al. 1981;

118 Richards \& Coley 2007). Higher plant productivity and species richness in wet, aseasonal forests 119 may improve the fitness of predators by providing more complementary food and shelter options

(Root 1973; Russell 1989). However, high predation pressure and the resulting lower abundance of insect herbivores in wetter forests would counter any tendency for more pronounced herbivore-imposed CNDD to act as a mechanism increasing tree species richness with rainfall. Despite the long-standing recognition of the impact of predators on herbivory (Coley \& Barone 1996), few studies have measured predation pressure across tropical rainfall gradients (Stireman et al. 2005; Connahs et al. 2011), and we are unaware of studies documenting trends in herbivory and predation simultaneously across multiple sites.

Overall, insect herbivory could explain the increase of tree species richness towards wetter tropical forests, if it increases with rainfall, is higher on locally abundant versus rare species, and is not limited by predation pressure at wet sites. Working in a network of sites across a steep gradient of rainfall and tree diversity in Panama, Central America, we quantified insect herbivory of tree saplings in six natural forest sites in relation to the local abundances of a total set of 42 focal tree species. At the same time, predation pressure on insect herbivores was assessed in one dry and one wetter forest along the same gradient. We tested the hypotheses that 
134 (1) insect herbivory increases with rainfall, (2) insect herbivory increases with local tree and 135 sapling abundance, and (3) predation pressure remains unchanged with rainfall.

136

137

138

\section{METHODS}

FIELD SITES. - The study was performed in forests in Central Panama, along a steep rainfall gradient. Within just $65 \mathrm{~km}$, mean annual rainfall increases from the semi-deciduous forests at the Pacific side with $\sim 1600 \mathrm{~mm} / \mathrm{yr}$ and a pronounced dry season from December to April $(\sim 129$ d), to the evergreen forests at the Caribbean side with $\sim 4000 \mathrm{~mm} / \mathrm{yr}$ and a $\sim 27 \mathrm{~d}$ shorter dry season (Engelbrecht et al. 2007). Tree richness ranges from 49 to 165 species per forest hectare along the gradient and is positively correlated with rainfall (Pyke et al. 2001). This study was conducted in six lowland 1-ha $(100 \times 100 \mathrm{~m})$ forest sites, spanning almost the full range of variation in rainfall and tree species richness (Table 1). Adult trees and large saplings $(\geq 1 \mathrm{~cm}$ diameter at breast height, dbh), hereafter referred to as 'trees', were censused throughout each site (Condit 1998b, this study) and seedlings and small saplings ( $\geq 20 \mathrm{~cm}$ tall and $<1 \mathrm{~cm} \mathrm{dbh),}$ hereafter 'saplings', in 400 1x1 m plots per 1-ha site (Comita et al. 2007 for census methods). Herbivory and predation pressure were assessed between late May and August 2014 during the rainy season, when insect abundance (Coley \& Barone 1996) and predation pressure on insects (Molleman et al. 2016) is highest. Mean annual rainfall was calculated based on $20-80$ year rainfall records in a network of rainfall stations (Steve Paton, pers. comm.).

FOCAL SPECIES AND PLANT MATERIAL. - We focused on shade-tolerant tree species, which contribute the majority of species and stems at these sites (Welden et al. 1991), to avoid 
conflicting impacts of plant life history strategies and growth form. Species were selected to cover a wide range of abundances (based on census data from Condit $1998 \mathrm{~b}$ and this study). The very rarest species, often represented by only one individual per hectare, were excluded to allow replication within sites. Specifically, species were included only if at least three saplings (50-200 $\mathrm{cm}$ tall, $\leq 1 \mathrm{~cm} \mathrm{dbh}$ ) could be found in the understory (i.e. excluding tree-fall gaps) of a 1-ha site. We did not sample saplings located in conspecific clusters, i.e. more than three conspecific saplings standing in close proximity, to match scales of herbivory and abundance data. With these criteria, we selected 42 focal species (representing 35 genera, 21 families, and 12 orders; Table S1), of which some were sampled in more than one site amounting to 56 species-by-site combinations. Due to rapid species turnover across the gradient (Condit 1998a), focal species differed among sites. Only one species, Lacistema aggregatum P.J.Bergius (Rusby) (Malpighiales: Lacistemataceae), could be included in all six sites allowing for assessment of intraspecific variation in herbivory across the gradient. We measured 5-11 species per site with 3-18 individuals per species (mean 11.54; Table S1), and a total of 680 saplings across all sites.

HERBIVORY MEASUREMENTS. - We focused on folivory and did not investigate more cryptic forms of insect herbivory (e.g., stem-boring, root-feeding). Five fully expanded, young, healthy, shaded and undamaged leaves per sapling were haphazardly chosen and tagged with numbered aluminum rings around the petioles. We focused on fully expanded leaves because herbivory on mature leaves can affect seedling survival negatively (Eichhorn et al. 2010). In contrast, plant mortality has been found to be unaffected by herbivory on young leaves (Eichhorn et al. 2010), although it is higher than herbivory on mature leaves (Coley \& Barone 1996). Leaves with low levels of previous damage $(<2 \%$ of leaf area) were included in cases where too few undamaged 
leaves were found. Prior damage was measured with a millimeter grid. Leaves were collected to analyze herbivore damage about 50 days after tagging (minimum $46 \mathrm{~d}$, maximum $58 \mathrm{~d}$ ), alternating between drier and wetter sites. Missing leaves (3.29\% of all leaves) were not considered, as the cause of leaf loss could not be determined. Overall, 3209 leaves (3-5 leaves per sapling, mean 4.7) were collected.

Herbivory was assessed as the percentage leaf area removed relative to estimated total leaf area. Brown areas were considered as secondary damage and not included in the herbivory measurements. No damage of leaf miners or gall formers occurred on the tagged leaves during our sampling period. Leaves were covered and flattened with non-reflecting glass on a white background and photographed next to a $1 \mathrm{~mm}$ scale with a Nikon Coolpix P5000 camera. Photographs were analyzed for remaining and estimated total leaf area using ImageJ 1.46r (Rasband 2006). In the few cases where large parts of the leaf were missing and the original leaf outline could not be resolved, the median leaf area of all conspecific leaves was used as an estimate of the initial total leaf area. Any damage registered prior to the observation period was subtracted from the measured herbivory.

PREDATION PRESSURE. - Predation pressure was assessed in two of our sites (Metropolitano, Charco) in July 2014 using artificial caterpillars (hereafter 'caterpillars'; Howe et al. 2009). The caterpillars (30 x $2.5 \mathrm{~mm}$, dark green color, Lewis Newplast) were odorless and non-toxic, and resembled undefended geometrid caterpillars. Members of the family Geometridae feed on woody plants and are among the most commonly observed caterpillars in forests worldwide, including our Metropolitano site (Connahs et al. 2011).

In each site, 100 caterpillars were placed individually on shaded tree recruits $\leq 100 \mathrm{~cm}$ 
tall, $\geq 100 \mathrm{~cm}$ apart, with similar sized, entire, single leaves. Tree recruits were not identical to the saplings used for herbivory observations. Caterpillars were attached to the upper side of leaves with a small amount of quick-setting glue (Loctite Super Glue, Henkel) and examined for predator marks after $24 \mathrm{~h}, 48 \mathrm{~h}$ and $96 \mathrm{~h}( \pm 2 \mathrm{~h})$. Attacked caterpillars were collected. Fallen caterpillars without predator marks were reattached. The caterpillars and the experimental setup followed the protocols of a global citizen science project (Roslin et al. 2017).

Predator marks were clearly visible (Fig. S1) and classified into attacks by ants, birds, mammals, lizards, snails and slugs, and unidentified predators using reference pictures from the literature (e.g. Howe et al. 2009). Caterpillars showing several types of marks were scored as attacked caterpillars for each of the relevant predator groups. We excluded caterpillars that only showed marks by snails and slugs (which are not predators on real caterpillars) or unidentified marks (Charco: 34\% of caterpillars, Metropolitano: 33\%), and missing caterpillars (Charco 2\%, Metropolitano 1\%). Very high occurrence of snail and slug attacks (70\%) required the exclusion of a third, high rainfall site (San Lorenzo), initially included in the study.

STATISTICAL ANALYSES. - Individual sapling herbivory was assessed as median herbivory of three to five leaves, because leaf herbivory data were heavily zero-inflated and non-normally distributed. For each sapling, we analyzed two measures of herbivory. First, we analyzed the probability of being attacked by herbivores by transforming sapling herbivory values into binary data (presence or absence of herbivory). Second, we quantified the amount of herbivory occurring on damaged individuals, including only saplings with a median herbivory greater than zero. We then tested whether the probability and amount of herbivory were significantly related to mean annual rainfall across sites, and to species' abundance within sites. 
Abundance was analyzed separately for trees and saplings to test for potentially different

effects of conspecific trees versus conspecific saplings on herbivory. We assessed species' abundances in three ways: (1) using counts of tree and sapling conspecifics within each 1-ha site; (2) transforming the counts of tree and sapling conspecifics within each 1-ha site into abundance ranks to account for variation in the total number of tree stems among sites. Abundance ranks were assigned across all tree species within a site, including non-focal species. The rarest species at each site, i.e. with fewest individuals within the respective 1-ha site, was assigned the lowest rank (=1); and (3) to improve comparability across our six sites and create a consistent abundance scale ranging from 0.01 (rare) to 1 (the most abundant species in each site), we standardized abundance ranks by dividing species' ranks by the total number of ranks per site. All three analyses yielded qualitatively similar results (Table S2, Fig. S2\&3). We therefore present only the third abundance measure, which improves across-site comparability by controlling for absolute abundance, in the text.

We fitted a generalized linear model with logit link function to analyze the relationship of the probability of herbivory with mean annual rainfall. The relationships of the probability of herbivory with tree abundance and with sapling abundance were analyzed with separate generalized linear mixed-effects models with logit link function. Field site was included as a random effect.

We then analyzed the amount of herbivory occurring on damaged individuals. Species with fewer than three attacked individuals per site were excluded from analyses to ensure reliable median values. The correlation of species' median herbivory with mean annual rainfall, tree abundance, and sapling abundance was tested using non-parametric Spearman rank sum tests, while controlling for the effect of field site for the two latter correlations by calculating partial 
correlation coefficients using the 'ppcor' package in R (Kim 2015).

Additionally, we analyzed how the probability and amount of herbivory varied with tree and sapling abundance within each site to check whether across-gradient patterns were mirrored in within-site patterns. We used generalized linear models with logit link function for probability of herbivory, and Spearman rank sum tests for amount of herbivory.

For L. aggregatum, the only species found at all six sites, we analyzed the probability of herbivory and individual median amount of herbivory as a function of mean annual rainfall, tree abundance, and sapling abundance (for the results of all three abundance methods see Table S2, Fig. S4\&5), separately, as described above. Herbivory data from all six sites were considered in the binary analysis; in the continuous analysis, the wettest site was excluded, since only one individual showed a median herbivory above zero.

Predation pressure was calculated as the proportion of caterpillars attacked and compared between the two sites with an equal proportions test. We also compared predation pressure of each predator group separately between the sites, using generalized linear models with binomial errors and cloglog link to model the probability of a caterpillar showing a particular attack mark (e.g., characteristic of ants or birds). Since caterpillars were removed from the forest after the first sign of attack by any predator, we included a $\log ($ time $)$ offset in the models to adjust for differences in the length of exposure to predators. All statistical analyses were performed using R v3.1.2 (R Core Team 2015).

\section{RESULTS}

The overall amount of leaf area removed by insect herbivores over the course of the study was 
272 low (mean 1.06\%, minimum 0\%, maximum 85.53\%; Table S1). Extrapolating mean annual

273 herbivory (dividing mean herbivory by the days of exposure and multiplying the result by the

274365 days of a year), corresponds to a mean herbivory of about eight percent per year. In total,

27526.8 percent of the leaves (861 of 3209), and 61 percent of the saplings (416 of 680) experienced

276 herbivory during our study.

277

278

279

280

281

282

283

284

285

286

HERBIVORY ACROSS THE GRADIENT. - Counter to our hypothesis, the probability of herbivory (Fig. 1A) and the amount of herbivory (Fig. 1C) decreased significantly with rainfall. For example, mean probability and median amount of herbivory were $\sim 1.5$ and 4.4 times higher, respectively, at the driest compared to the wettest site (Panama Pacifico: probability $=0.61$, amount $=0.31 \%$; San Lorenzo: probability $=0.42$; amount $=0.07 \%$.

HERBIVORY AND ABUNDANCE. - Our hypothesis of an increase in herbivory with tree species abundance was only partially supported. Analyzing all sites together, the probability of herbivory increased significantly with sapling abundance, but not with tree abundance (Fig. 2A\&B).

Moreover, the amount of herbivory was not related to either tree or sapling abundance (Fig. $2 C \& D)$. Analyzing each site separately, we did not find a consistent relationship between species abundance and the probability or the amount of herbivory within each site, and in most cases there was no significant relationship (Table S3).

INTRASPECIFIC VARIATION IN HERBIVORY. - In L. aggregatum, neither the probability of herbivory (Fig. 1B), nor the amount of herbivory (Fig. 1D) were related to rainfall. The amount of herbivory was highest at a site with intermediate rainfall (Charco; Fig. 1D), in contrast to the 
negative relationship between herbivory and rainfall observed across all species. The probability of herbivory was significantly positively related to the abundance of $L$. aggregatum saplings, but not trees across sites (Fig. 3A\&B). The amount of herbivory of L. aggregatum was not significantly related to either tree or sapling abundance (Fig. 3C\&D).

\section{PREDATION PRESSURE. - Predation pressure, i.e. the overall proportion of attacked caterpillars} after 4 days, was higher in the wetter site than in the dry site (wet: $54.7 \%, 35$ of 64 caterpillars; dry: $22.7 \%, 15$ of 66 ; Fig. 4A). Attack marks mainly originated from ants, birds, and mammals in descending frequency (Fig. 4B). For these different predator groups, the probability of attack was significantly higher in the wetter site than the dry site (Fig. 4B), for attack by ants (glm: $z=-$ 2.96, $P=0.003)$, with a similar, but non-significant, trend for attacks by birds $(\mathrm{z}=-1.896, P=$ $0.058)$ and mammals $(\mathrm{z}=-1.915, P=0.055)$. Only one caterpillar was attacked by a lizard.

\section{DISCUSSION}

Herbivory was overall low, equivalent to eight percent per year and comparable to values reported for tropical forests in some previous studies (Eichhorn et al. 2010; Baltzer \& Davies 2012; Table S1). Studies reporting higher herbivory rates usually defined herbivory more broadly, e.g. including lost leaves (e.g. Brenes-Arguedas et al. 2009) or discolored parts of the leaf (e.g. Plath et al. 2012), or used means instead of more conservative medians of individual herbivore damage levels (e.g. Plath et al. 2012). Nevertheless, even small amounts of herbivory on mature leaves can increase tree recruit mortality (Eichhorn et al. 2010) and reduce sapling growth, thereby delaying the age of first reproduction and enhancing the risk of mortality 
(Marquis 1984; Sullivan 2003).

HERBIVORY ACROSS THE GRADIENT. - Counter to our prediction, both the probability and the amount of herbivory were lower in wetter forests (Fig. 1A\&C). Insect herbivory can be suppressed at low annual rainfall (Brenes-Arguedas et al. 2009), a pattern hypothesized to result from insects experiencing an increased risk of desiccation, and/ or seasonal resource shortages in drier tropical forests (Givnish 1999). With $\sim 1750 \mathrm{~mm} / \mathrm{yr}$, the driest forest in our study was still relatively humid, with a dry season that may be too short to suppress herbivore pressure substantially. Nonetheless, the decreasing herbivory with increasing rainfall we report here agrees with several other studies showing higher herbivory rates on shade-tolerant plants in dry than in wet tropical forests (Coley \& Barone 1996; Leigh et al. 2004; Dirzo \& Boege 2008). Along the same gradient, Gaviria and Engelbrecht (2015) found evidence for a stronger impact of herbivory on plant establishment in a dry than a wet forest. Further support is provided by Novotny (2009), who questioned the idea of insect limitation through increased desiccation risk and presented evidence that insects have wider environmental tolerances than previously assumed.

Four main processes may contribute to higher herbivory in dry compared to wet sites. First, more intense and more frequent rainfall events in wet forests may constrain insect abundance and activity simply through the physical force of heavy rain (Wirth \& Leal 2001; Purcell \& Avilés 2008). Second, a higher predation pressure, i.e. top-down control, on herbivores in wetter forests, as indicated by our results (Fig. 4A\&B) and several other studies (Stireman et al. 2005; Richards \& Coley 2007; Purcell \& Avilés 2008) may decrease insect herbivore abundance (Richards \& Coley 2007) and feeding activity (Mazía et al. 2004; Stireman et al. 
2005; Rodríguez-Castañeda 2013) in wet forests (see below). Third, anti-herbivore defense of leaves may be more pronounced in wet forest tree species and may effectively deter insect herbivores (Coley \& Barone 1996; Julian Gaviria \& Bettina M.J. Engelbrecht, pers. comm.). Deciduous, dry forest trees produce short-lived leaves (Santiago et al., 2004), which can easily be replaced due to lower light limitation and therefore do not need high chemical or mechanical protection against herbivores. In contrast, wet-forest trees invest more in their long-lived leaves, arming them with stronger structural defenses (Santiago et al., 2004). Lastly, the Panamanian rainfall gradient is accompanied by an increase in tree species richness, which may decrease herbivory in wetter forests via the higher number of different plant stimuli in more diverse plant communities that may hinder host recognition for specialized herbivores (Tahvanainen \& Root 1972; Jactel \& Brockerhoff 2007; Castagneyrol et al. 2014). Peters (2003) has shown that at a given density of conspecific trees, negative density dependent mortality decreased with the number of heterospecific trees in a tropical forest, attributing this effect to herd immunity. Despite the relatively low number of leaves measured per species per site, our study is, to our knowledge, the most comprehensive analysis of insect herbivory in forest ecosystems across a rainfall gradient. While our data apply only to folivores, our results, together with earlier studies (Leigh et al. 2004; Mazía et al. 2004; Dirzo \& Boege 2008), run counter to the theoretical prediction that insect herbivory increases with rainfall and is therefore a more important determinant of plant population dynamics and community composition in wetter tropical forests (Connell 1971; Givnish 1999; Leigh et al. 2004). CNDD may nevertheless contribute to high tree alpha-diversity via mechanisms other than herbivory, such as mortality from pathogens (Bagchi et al. 2014) or intraspecific competition for resources, or by acting more strongly on other lifestages (Zhu et al. 2015). 
HERBIVORY AND ABUNDANCE. - The probability of herbivory increased with higher conspecific sapling abundance (Fig. 2B). However, the probability of herbivory was not related to tree abundance (Fig. 2A), and the amount of herbivory did not increase with abundance (Fig. 2C\&D). In addition, when analyzing sites separately, we did not find a consistent relationship between abundance and herbivory (Table S3). Insect herbivores may respond to host leaf biomass rather than tree number. However, it is unlikely that in all our sites the rarest species had a similar or higher leaf biomass, i.e. larger and/ or more leaves, than the abundant species and such effects are therefore unlikely to have biased our results. We may have underestimated herbivory abundance relationships, if insects respond to tree density at very small scales, because we avoided conspecific plant clusters in our sampling protocol. Nevertheless, our results indicate that the relationship between local plant abundance and insect herbivory is complex.

The higher probability of herbivory in tree species with higher sapling abundance supports our hypothesis and is in line with a rare species advantage facilitating species coexistence (Connell 1984). In abundant tree species, shorter distances between conspecific saplings may favor host-switching from one sapling to another, which has been suggested to benefit insect herbivores via intraspecific diet mixing (Plath et al. 2012; Hambäck et al. 2014). In contrast, saplings of rare species are likely to be more isolated from conspecifics, reducing the encounter rate and the probability of herbivory. Additionally, the diversity of cues emitted by plant species in tropical forests may cause a chemical masking of isolated tree individuals, further complicating host-finding for herbivores of rare species (Tahvanainen \& Root 1972). Thus, a higher distance between individual plants combined with insect dispersal limitation may explain our result of the reduced probability of herbivory in rare species. 
The lack of an increase in the amount of herbivory across abundance was, in contrast,

unexpected and may seem at odds with a rare species advantage. A lower probability of herbivory in rare species alone may nevertheless allow the persistence of rare species within a community, if the saplings of rare species benefit enough from escape of herbivore attack to gain a competitive advantage compared to abundant species. The results thus point towards more complex processes influencing the relationship between host abundance and herbivory than expected.

INTRASPECIFIC VARIATION IN HERBIVORY. - In the one species studied across all six forest sites, L. aggregatum, the probability of herbivory increased with conspecific sapling abundance across sites, but was not related to conspecific tree abundance (Fig. 3A\&B). Further, the amount of herbivory was not related to either tree or sapling abundance. Thus, the relationship of herbivory with abundance in L. aggregatum was similar to the pattern found in our across-species analyses. However, neither the probability nor the amount (Fig. 1B\&D) of herbivory in L. aggregatum was related to rainfall, in contrast to the across-species pattern of decreasing herbivory with rainfall. A recent study of seed predation by insects across the same set of field sites in Panama also found no significant association between rainfall and levels of insect attack on fifteen focal plant species (Jeffs et al., in revision). The divergent herbivory patterns in L. aggregatum imply that tree species may differ substantially in the relation of herbivory to rainfall. In addition to rainfall, other abiotic (e.g. nutrients, light) and biotic conditions (herbivore and plant community composition) vary across sites and, depending on species-specific ecological optima for plant and associated herbivore species, may strongly impact plant-insect interactions (Loranger et al. 2013; Hambäck et al. 2014). These results indicate that studies focusing on single plant species 
are unlikely to yield representative results and highlight the need for community level studies.

PREDATION PRESSURE. - The overall predation pressure and the probability of attack by each of the three main predator groups (ants, birds, mammals) were higher in the wetter than in the dry site (Fig. 4A\&B). This trend is consistent with a previous study showing increasing predation with rainfall (Stireman et al. 2005), and with the notion that ants and birds are the most important predators of tropical insect herbivores (Tvardikova \& Novotny 2012; Sam et al. 2015). Nevertheless, with only two sites, our results should be interpreted cautiously since the sites may differ in other ways that could influence predation rates (e.g., our drier site is located within an urbanized area, which may reduce predator abundances).

The relative importance of predator-imposed, top-down control compared to bottom-up regulation of herbivores has been hypothesized to increase with stability of climatic factors regulating ecosystem productivity, such as rainfall (enemies hypothesis; Root 1973; Oksanen et al. 1981). High and stable primary productivity is proposed to result in high and stable herbivore abundance throughout the year, which may result in a higher number of predators. In line with this prediction, Ferger et al. (2014) found that higher precipitation indirectly increases African insectivore bird richness, possibly mediated by an increase in vegetation complexity and biomass of invertebrates. Higher tree species richness in wetter forests may enhance the supply of alternative and complementary food sources, such as nectar, which may stabilize predator populations and improve their fitness (Russell 1989). Further, predators may be less sensitive to the physical effects of rainfall than herbivores due to their larger size and greater robustness. Predation on larval stages poses a substantial mortality risk for herbivores and can additionally lead to behavioral changes, causing insect herbivores to spend relatively less time 
433 feeding and more time sheltering (Mazía et al. 2004; Tvardikova \& Novotny 2012). In

434 combination, lethal and behavioral effects of predators have been shown to halve herbivory

435 (Mazía et al. 2004). Increased predation pressure towards wetter forests is therefore likely to

436 contribute to the unexpected decrease of herbivory with rainfall that we observed.

represents the most comprehensive investigation of insect herbivory in forest ecosystems across

440

441

442

CONCLUSION. - To the best of our knowledge, our analysis based on data from six forest sites a rainfall gradient. Our data suggest that the increase in the probability of herbivory with local sapling abundance could facilitate tree species co-existence. It remains to be tested, however, whether the lower probability of herbivory in rare tree species is indeed translated into a competitive advantage.

We did not find support for the prediction that higher insect herbivory contributes to the increase in tree species richness with rainfall across the Isthmus of Panama. Rather, herbivory strongly decreased with rainfall, which may be at least partly explained by higher predation pressure in wetter forests. Our study highlights the need to incorporate multiple trophic levels when assessing the factors contributing to patterns of species richness.

Acknowledgements: We thank David Brassfield, Blexein Conteras, Carlos Green, and Roni Saenz for help with sapling identification in the field. Anna Pike, Tom Lewis, Lily Lewis, and Joe Lewis assisted with caterpillar predation fieldwork. We thank the Spatial Foodweb Ecology Group from the University of Helsinki for providing standardized artificial caterpillars. The Smithsonian Tropical Research Institute (STRI) provided logistical support for the study, and the Autoridad Nacional de Ambiente (ANAM) granted research permits for fieldwork. We thank 
Agencia Panamá Pacifico (APP) and David Roubik for special permission to work in their forests (private properties), and the Center for Tropical Forest Science of the Smithsonian Tropical Research Institute for providing data on tree abundances. Set up and censuses of the forest sites were supported by the Ohio State University, Yale University, and the UK National Environment Research Council (standard grant NE/J011169/1 to OTL).

Conflict of Interest: The authors declare that they have no conflict of interest.

Data availability: The data used in this study are archived at the Dryad Digital Repository ().

\section{Literature cited:}

Bagchi, R., Gallery, R.E., Gripenberg, S., Gurr, S.J., NArAyan, L., AdDis, C.E., FRECKLETON, R.P., LEWIS, O.T. 2014. Pathogens and insect herbivores drive rainforest plant diversity and composition. Nature 506: 85-88. doi: 10.1038/nature12911

BALTZER, J.L., DAVIES, S.J. 2012. Rainfall seasonality and pest pressure as determinants of tropical tree species' distributions. Ecol Evol 2: 2682-2694. doi: 10.1002/ece3.383

Bonebrake, T.C., Boggs, C.L., McNally, J.M., Ranganathan, J., Ehrlich, P.R. 2010. Oviposition behavior and offspring performance in herbivorous insects: consequences of climatic and habitat heterogeneity. Oikos 119: 927-934. doi: 10.1111/j.16000706.2009.17759.x

Brenes-Arguedas, T., Coley, P.D., Kursar, T.A. 2009. Pests vs. drought as determinants of plant distribution along a tropical rainfall gradient. Ecology 90: 1751-1761. doi: $10.1890 / 08-1271.1$ 
Castagneyrol, B., Jactel, H., Vacher, C., Brockerhoff, E.G., Koricheva, J. 2014. Effects of plant phylogenetic diversity on herbivory depend on herbivore specialization. J App Ecol 51: 134-141. doi: 10.1111/1365-2664.12175

Coley, P.D., BARONE, J.A. 1996. Herbivory and plant defenses in tropical forests. Ann Rev Ecol Syst 27: 305-335. doi: 10.2307/1942495

Comita, L.S., Aguilar, S., PÉrez, R., LaO, S., Hubbell, S.P. 2007. Patterns of woody plant species abundance and diversity in the seedling layer of a tropical forest. J Veg Sci 18: $163-174$.

COMITA, L.S., ENGELBRECHT, B.M.J. 2014. Drought as a driver of tropical tree species regeneration dynamics and distribution patterns. In Coomes, D.A., Burslem, D.R.F.P., Simonson, W. (Eds.) Forests and Global Change. Cambridge University Press.

Comita, L.S., Muller-Landau, H.C., Aguilar, S., Hubbell, S.P. 2010. Asymmetric density dependence shapes species abundances in a tropical tree community. Science 329: 330-329. doi: 10.1126/science.1190772

Comita, L.S., QueEnBorough, S.A., MurPhy, S.J., EcK, J.L., Xu, K., KRISHNAdAs, M., BeCKMAN, N., ZHU, Y. 2014. Testing predictions of the Janzen-Connell hypothesis: a meta-analysis of experimental evidence for distance- and density-dependent seed and seedling survival. J Ecol 102: 845-856. doi: 10.1111/1365-2745.12232

CONDIT, R. 1998a. Ecological implications of changes in drought patterns: shifts in forest composition in Panama. Clim Chang 39: 413-427. doi: 10.1023/A:1005395806800 Condit, R. 1998b. Part 2. Field methods for a large forest plot. In Condit, R. (Ed.) Tropical forest census plots, pp. 15-99. Springer, Berlin.

Connahs, H., Aiello, A., Van Bael, S., RodríGuez-Castañeda, G. 2011. Caterpillar 
abundance and parasitism in a seasonally dry versus wet tropical forest of Panama. $\mathrm{J}$ Trop Ecol 27: 51-58. doi: 10.1017/S0266467410000568

CONNELL, J.H. 1971. On the role of natural enemies in preventing competitive exclusion in some marine animals and in rain forest trees. In Den Boer, P.J., Gradwell, G.R. (Eds.) Dynamics of Population, pp. 298-312. Pudoc, Wageningen.

Connell, J.H., TraceY, J.G., WeBB, L.J. 1984. Compensatory recruitment, growth, and mortality as factors maintaining rain forest tree diversity. Ecol Monogr 54: 141-164. doi: $10.2307 / 1942659$

Davidar, P., PuYravaud, J.P., Leigh, E.G. 2005. Changes in rain forest tree diversity, dominance and rarity across a seasonality gradient in the Western Ghats, India. J Biogeogr 32: 493-501. doi: 10.1111/j.1365-2699.2005.01165.x

Dirzo, R., BoEge, K. 2008. Patterns of herbivory and defense in tropical dry and rain forests. In Carson, W., Schnitzer, A. (Eds.) Tropical Forest Community Ecology, pp 63-78. Blackwell Science, West Sussex.

EichHorn, M.P., Nilus, R., Compton, S.G., Hartley, S.E., Burslem, D.F.R.P. 2010.

Herbivory of tropical forest tree seedlings correlates with future mortality. Ecology 91: 10921101. doi: 10.1890/09-0300.1

Engelbrecht, B.M.J., Comita, L.S., Condit, R., Kursar, T.A., Tyree, M.T., Turner, B.L., HuBBELL, S.P. 2007. Drought sensitivity shaped species distribution patterns in tropical forests. Nature 447: 80-82. doi: 10.1038/nature05747

Ferger, S.W., Schleuning, M., Hemp, A., Howell, K.M., BöHning-Gaese, K. 2014. Food resources and vegetation structure mediate climatic effects on species richness of birds. Global Ecol Biogeogr 23: 541-549. doi: 10.1111/geb.12151 
GAVIRIA, J., ENGELBRECHT, B.M.J. 2015. Effects of drought, pest pressure and light availability on seedling establishment and growth: Their role for distribution of tree species across a tropical rainfall gradient. PloS ONE 10: e0143955. doi:

\subsection{1/journal.pone.0143955}

GIVNISH, T.J. 1999. On the causes of gradients in tropical tree diversity. J Ecol 87: 193-210. doi: 10.1046/j.1365-2745.1999.00333.x

Hambäck, P.A., Inouye, B.D., Andersson, P., Underwood, N. 2014. Effects of plant neighborhoods on plant-herbivore interactions: resource dilution and associational effects. Ecology 95: 1370-1383. doi: 10.1890/13-0793.1

Howe, A., LöVEI, G.L., NACHMAN, G. 2009. Dummy caterpillars as a simple method to assess predation rates on invertebrates in a tropical agroecosystem. Entomol Exp Appl 131:325329. doi: $10.1111 / j .1570-7458.2009 .00860 . x$

JACTEL, H., BROCKERHOFF, E.G. 2007. Tree diversity reduces herbivory by forest insects. Ecol Lett 10: 835-848. doi: 10.1111/j.1461-0248.2007.01073.x

JANZEN, D.H. 1970. Herbivores and the number of tree species in tropical forests. Am Nat 104: 501-528.

Jeffs, C., Kennedy, P., Griffith, P., GriPenberg, S., Markesteijn, L., Lewis, O.T. In revision. Seed predation by insects across a tropical forest precipitation gradient. Ecol Entomol.

KIM, S. 2015. ppcor: An R Package for a Fast Calculation to Semipartial Correlation Coefficients. Communications for Statistical Applications and Methods 22: 665-674.

Leigh, E.G., Davidar, P., Dick, C.W., Puyravaud, J.P., Terborgh, J., ter Steege, H., WRIGHT, S.J. 2004. Why do some tropical forests have so many species of trees? Biotropica 36: 447-473. doi: 10.1111/j.1744-7429.2004.tb00342.x 
Loranger, J., Meyer, S.T., Shipley, B., Kattge, J., Loranger, H., Roscher, C., Wirth, C., WEISSER, W.W. 2013. Predicting invertebrate herbivory from plant traits: Polycultures show strong nonadditive effects. Ecol 94: 1499-1509. doi: 10.1890/12-0328.1

MARQUIS, R.J. 1984. Leaf herbivores decrease fitness of a tropical plant. Science 226: 537-539. doi: $10.1126 /$ science. 226.4674 .537

Mazía, C.N., KitzBerger, T., Chaneton, E.J. 2004. Interannual changes in folivory and bird insectivory along a natural productivity gradient in northern Patagonian forests. Ecography 27: 29-40. doi: 10.1111/j.0906-7590.2004.03641.x

Molleman, F., Remmel, T., Sam, K. 2016. Phenology of predation on insects in a tropical forest: temporal variation in attack rate on dummy caterpillars. Biotropica 48: 229-236. doi: 10.1111/btp. 12268

Norghauer, J.M., MALColm, J.R., ZimMERMAN, B.L. 2006. Juvenile mortality and attacks by a specialist herbivore increase with conspecific adult basal area of Amazonian Swietenia macrophylla (Meliaceae). J Trop Ecol 22: 451-460. doi: 10.1111/j.17524598.2008.00035.x

NovotNY, V. 2009. Beta diversity of plant-insect food webs in tropical forests: a conceptual review. Insect Conserv Divers 2: 5-9. doi: 10.1111/j.1752-4598.2008.00035.x

Oksanen, L., Fretwell, S.D., Arruda, J., Niemelä, P. 1981. Exploitation ecosystems in gradients of primary productivity. Am Nat 118: 240-261.

Otway, S.J., Hector, A., LAwTON, J.H. 2005. Resource dilution effects on specialist insect herbivores in a grassland biodiversity experiment. J Anim Ecol 74: 234-240. doi: $10.1111 / \mathrm{j} .1365-2656.2005 .00913 . x$

Paine, C.E.T., Norden, N., Chave, J., Forget, P.M., Fortunel, C., DeXter, K.G., Baraloto, 
C. 2012. Phylogenetic density dependence and environmental filtering predict seedling mortality in a tropical forest. Ecol Lett 15: 34-41. doi: 10.1111/j.1461-0248.2011.01705.x

PETERS, H.A. 2003. Neighbour-regulated mortality: the influence of positive and negative density dependence. Ecol Lett 6: 757-765. doi: 10.1046/j.1461-0248.2003.00492.x

Plath, M., Dorn, S., Riedel, J., Barrios, H., Mody, K. 2012. Associational resistance and associational susceptibility: specialist herbivores show contrasting responses to tree stand diversification. Oecologia 169: 477-487. doi: 10.1007/s00442-011-2215-6

Purcell, J., AVILÉs, L. 2008. Gradients of precipitation and ant abundance may contribute to the altitudinal range limit of subsocial spiders: insights from a transplant experiment. Proc $\mathrm{R}$ Soc B 275: 2617-2625. doi: 10.1098/rspb.2008.0582

Pyke, C.R., Condit, R., Aguilar, S., LaO, S. 2001. Floristic composition across a climatic gradient in a neotropical lowland forest. J Veg Sci 12: 553-566. doi: 10.2307/3237007

R CORE TEAm. 2015. R: A language and environment for statistical computing. R Foundation for Statistical Computing. Vienna, Austria.

RASBAND, W. 2006. ImageJ 1.36b. National Institutes of Health, Bethesda, MD.

RichardS, L.A., COLEY, P.D. 2007. Seasonal and habitat differences affect the impact of food and predation on herbivores: a comparison between gaps and understory of a tropical forest. Oikos 116: 31-40. doi: 10.1111/j.2006.0030-1299.15043.x

RodríGUeZ-CAStAÑEDA, G. 2013. The world and its shades of green: a meta-analysis on trophic cascades across temperature and precipitation gradients. Glob Ecol Biogeogr 22: 118130. doi: 10.1111/j.1466-8238.2012.00795.x

Root, R.B. 1973. Organization of a plant-arthropod association in simple and diverse habitats: The fauna of collards (Brassica Oleracea). Ecol Monogr 43: 95-124. doi: 
Roslin, T., Hardwick, B., Novotny, V., ET AL. 2017. Higher predation risk for insect prey at low latitudes and elevations. Science 356: 742-744. doi:10.1126/science.aaj1631

RUSSELL, E.P. 1989. Enemies Hypothesis: A Review of the Effect of Vegetational Diversity on Predatory Insects and Parasitoids. Env Entomol 18: 590-599.

Sam, K., Koane, B., Novotny, V. 2015 Herbivore damage increases avian and ant predation of caterpillars on trees along a complete elevational forest gradient in Papua New Guinea. Ecography 38: 293-300. doi: 10.1111/ecog.00979

Santiago, L.S., Kitajima, K., Wright, S.J., MulKey, S.S. 2004 Coordinated changes in photosynthesis, water relations and leaf nutritional traits of canopy trees along a precipitation gradient in lowland tropical forest. Oecologia 139: 495-502. doi: $10.1007 \% 2 F s 00442-004-1542-2$

STIREMAN III, J.O., DYER, L.A., JANZEN, D.H., ET AL. 2005. Climatic unpredictability and parasitism of caterpillars: implications of global warming. PNAS 102: 17384-17387. doi: 10.1073/pnas.0508839102

SulLIVAN, J.J. 2003. Density-dependent shoot-borer herbivory increases the age of first reproduction and mortality of neotropical tree saplings. Oecologia 136: 96-106. doi: $10.1007 / \mathrm{s} 00442-003-1233-4$

TAhVanainen, J.O., RoOT, R.B. 1972. The influence of vegetational diversity on the population ecology of a specialized herbivore, Phyllotreta cruciferae (Coleoptera: Chrysomelidae). Oecologia 10: 321-346. doi: 10.1007/BF00345736

Tvardikova, K., Novotny, V. 2012. Predation on exposed and leaf-rolling artificial caterpillars in tropical forests of Papua New Guinea. J Trop Ecol 28: 331-341. doi: 
618 Welden, C.W., Hewett, S.W., Hubbell, S.P., Foster, R.B. 1991. Sapling survival, growth, 619 and recruitment: relationship to canopy height in a Neotropical forest. Ecology 72: 35-50. doi: $620 \quad 10.2307 / 1938900$

621 WIRTH, R., LEAL, I.R. 2001. Does rainfall affect temporal variability of ant protection in $622 \quad$ Passiflora coccinea? Ecoscience 8: 450-453.

623 Zhu, Y., Comita, L.S., Hubbell, S.P., MA, K. 2015. Conspecific and phylogenetic density624 dependent survival differs across life stages in a tropical forest. J Ecol 103: 957-966. doi: 
626 TABLE 1 Study sites (1-ha), their coordinates, mean annual rainfall, and number of woody

627 species with stems $\geq 1 \mathrm{~cm}$ dbh (Condit $1998 \mathrm{~b}$ and this study) and small saplings ( $\geq 20 \mathrm{~cm}$ tall, $<$ $6281 \mathrm{~cm} \mathrm{dbh).}$

\begin{tabular}{|c|c|c|c|c|}
\hline Forest site & Location & $\begin{array}{l}\text { Rainfall } \\
{[\mathrm{mm} / \mathrm{yr}]}\end{array}$ & $\begin{array}{l}\text { Species No. } \\
\text { ( } \geq 1 \mathrm{~cm} \text { dbh) }\end{array}$ & $\begin{array}{l}\text { Species No. } \\
\text { (<1 cm dbh) }\end{array}$ \\
\hline Panama Pacifico & $8^{\circ} 56^{\prime} 36.60^{\prime \prime} \mathrm{N} 79^{\circ} 36^{\prime} 5.52^{\prime \prime} \mathrm{W}$ & 1756 & 74 & 46 \\
\hline Metropolitano & $8^{\circ} 59^{\prime} 40.52^{\prime \prime} \mathrm{N} 79^{\circ} 32^{\prime} 34.80^{\prime \prime} \mathrm{W}$ & 1874 & 47 & 33 \\
\hline Charco & $9^{\circ} 5^{\prime} 2.58^{\prime \prime} \mathrm{N} 79^{\circ} 39^{\prime} 48.24^{\prime \prime} \mathrm{W}$ & 2050 & 82 & 53 \\
\hline Pipeline Road & $9^{\circ} 9^{\prime 2} 23.40^{\prime \prime} \mathrm{N} 79^{\circ} 44^{\prime} 39.12^{\prime \prime} \mathrm{W}$ & 2311 & 130 & 79 \\
\hline Santa Rita & $9^{\circ} 20^{\prime} 8.08^{\prime \prime} \mathrm{N} 79^{\circ} 46^{\prime} 50.67^{\prime \prime} \mathrm{W}$ & 3053 & 201 & 108 \\
\hline San Lorenzo & $9^{\circ} 16^{\prime} 51.13^{\prime \prime N} 79^{\circ} 58^{\prime} 28.92^{\prime \prime} \mathrm{W}$ & 3203 & 161 & 65 \\
\hline
\end{tabular}


FIGURE 1 Relationship of (A, B) mean probability and (C, D) species median percentage of

630 insect herbivory with rainfall. Data are shown for $(\mathrm{A}, \mathrm{C})$ the full set of 42 tree species and for (B,

631 D) only Lacistema aggregatum. Point sizes reflect the (A, C) number of individuals measured

632 per plant species and the (B, D) the number of individuals per site. (A, B) Lines give results of

633 logistic regressions (continuous and dashed for significant and non-significant results,

634 respectively). (C, D) Results of Spearman rank sum tests are shown.
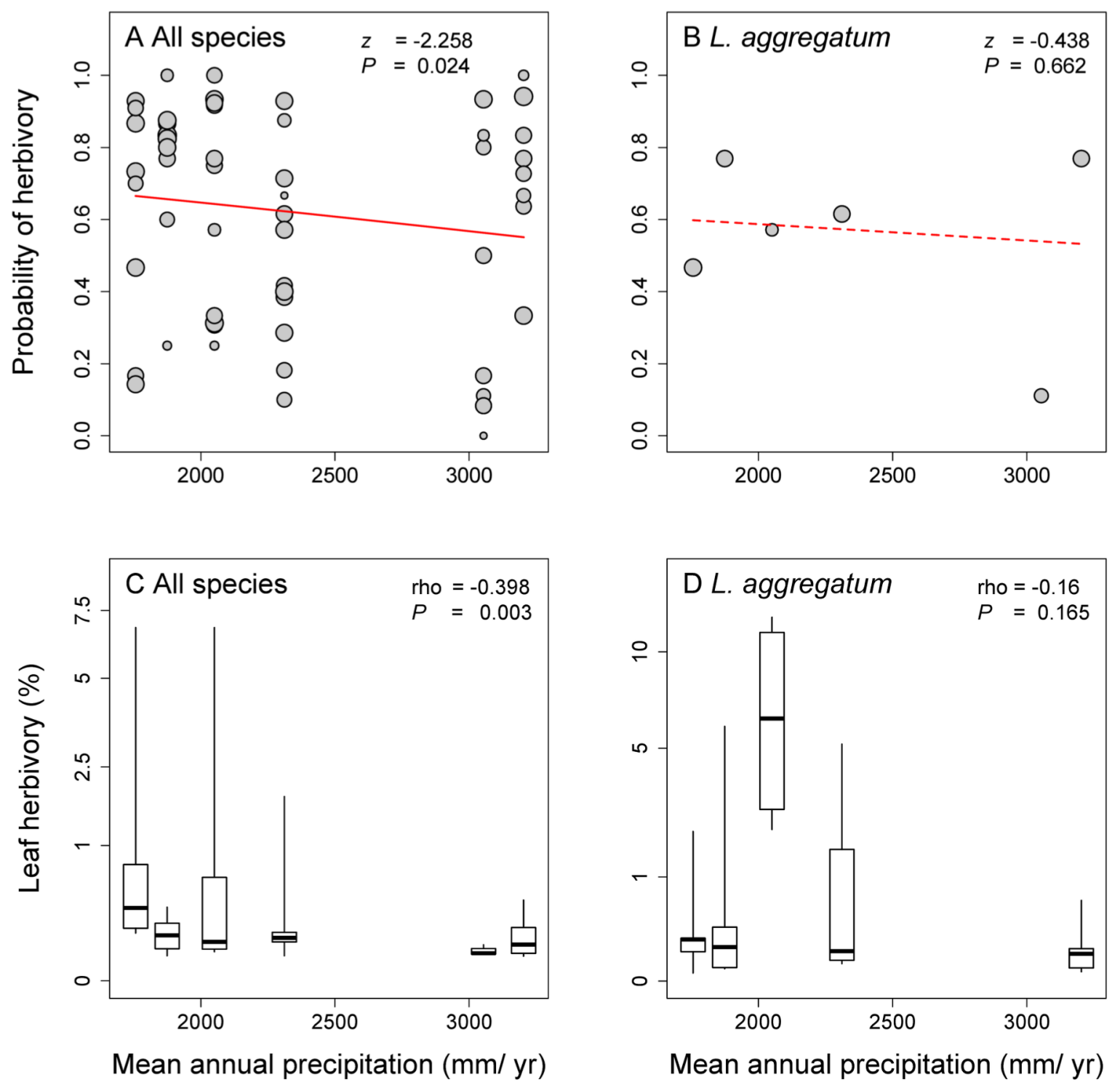
636 FIGURE 2 Relationship of (A, B) species' mean probabilities of herbivory and (C, D) median

637 amount of herbivory with (A, C) species tree and (B, D) sapling abundance ranks. Higher ranks

638 indicate higher individual numbers. Point sizes reflect the number of individuals measured per

639 plant species. Results from (A, B) logistic regressions and (C, D) Spearman rank sum tests are

640 given.
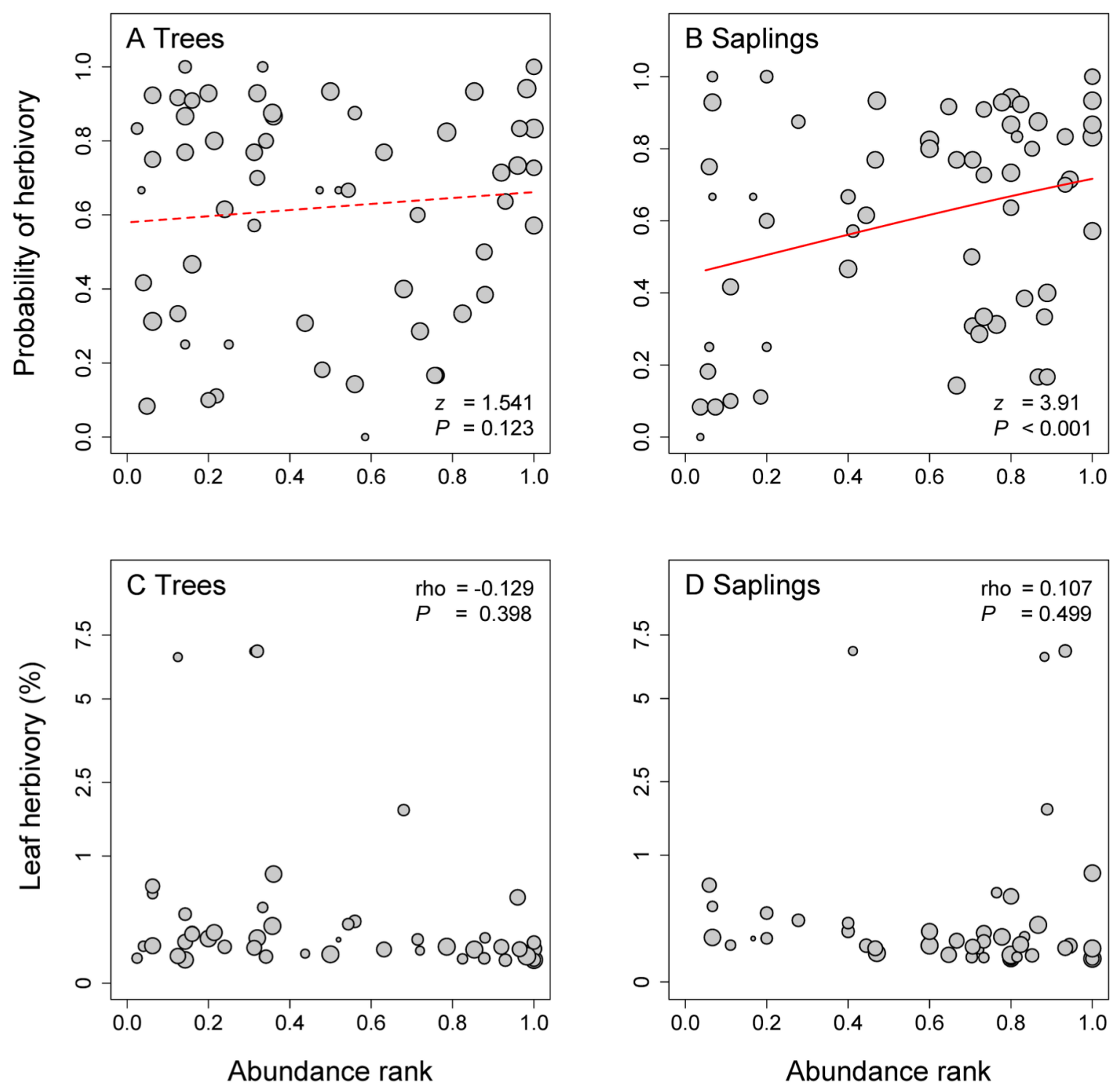

641

642 
FIGURE 3 Probability of (A, B) leaf herbivory and (C, D) amount of herbivory for saplings of 644 Lacistema aggregatum in relation to (A, C) tree and (B, D) sapling abundance rank. (A, B) Point 645 sizes reflect the number of individuals measured per site. (A, B) Lines give results of logistic 646 regressions. (C, D) Results of Spearman rank sum tests are presented.
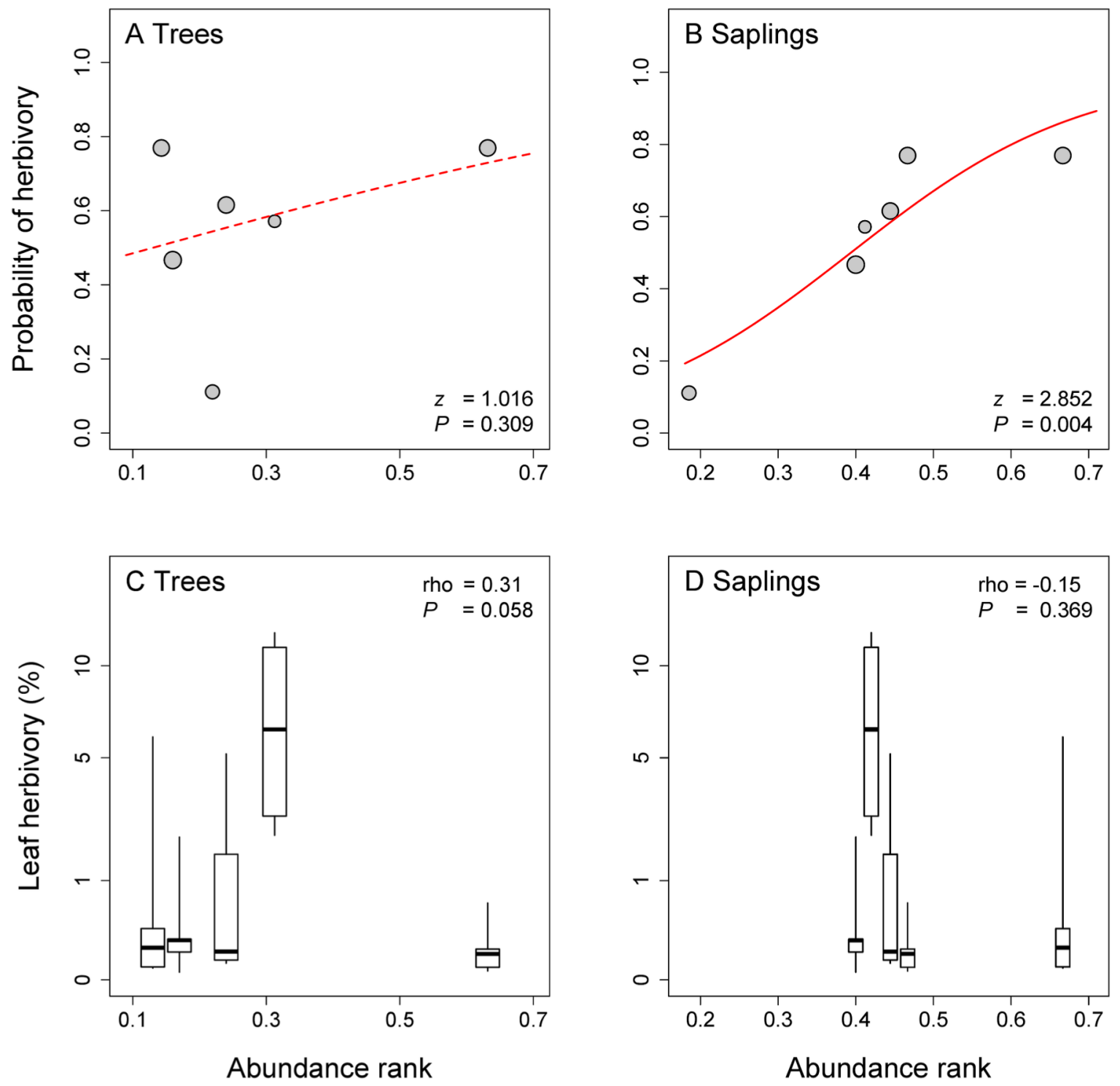
650 FIGURE 4 Predation pressure on artificial caterpillars in a drier (Metropolitano; $1874 \mathrm{~mm} / \mathrm{yr}$ )

651 and a wetter (Charco; $2050 \mathrm{~mm} / \mathrm{yr}$ ) tropical forest. Shown is (A) the proportion of caterpillars

652 attacked after 96 hours of exposure and the result of an equal proportions test, and (B) the

653 proportion of caterpillars showing attack marks of three main predator groups and the results of 654 generalized linear models.
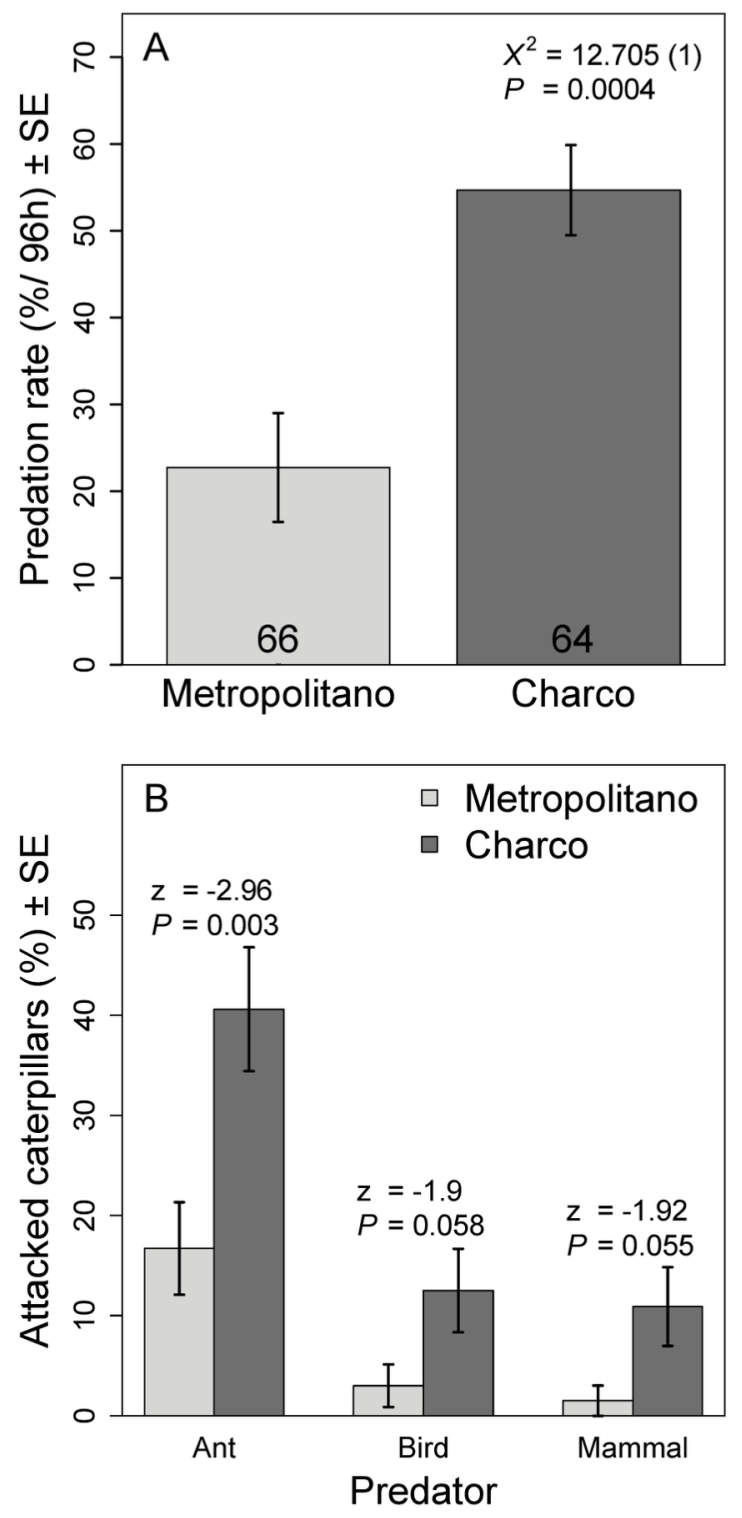